\title{
Biological properties of neural crest-derived multipotent stem cells from the bulge region of whisker follicle expanded under new culture conditions
}

\author{
R. G. Vasyliev ${ }^{1,2}$, A. E. Rodnichenko ${ }^{1,2}$, D. A. Zubov ${ }^{1,2}$, S. Y. Rymar ${ }^{3}$, \\ O. S. Gubar ${ }^{3}$, I. F. Labunets ${ }^{1}$, S. N. Novikova ${ }^{1}$ \\ ${ }^{1}$ State Institute of Genetic and Regenerative Medicine, National Academy of Medical Science of Ukraine \\ 67, Vyshhorodska Str., Kyiv, Ukraine, 04114 \\ ${ }^{2}$ Biotechnology laboratory ilaya.regeneration, Medical company ilaya ${ }^{\circledR}$ \\ 9, I. Kramskoho Str., Kyiv, Ukraine, 03115 \\ ${ }^{3}$ Institute of Molecular Biology and Genetics, NAS of Ukraine \\ 150, Akademika Zabolotnoho Str., Kyiv, Ukraine, 03680 \\ rvasiliev@ukr.net
}

\begin{abstract}
Aim. The work is aimed to obtain the culture of neural crest-derived multipotent stem cells (NC-MSCs) under new culture conditions and to investigate their biological properties. Methods. NC-MSCs were grown from the explants of the bulge region of whisker follicle of adult mice. The cell cultures were examined by the following methods: sphere-forming assay, directed multilineage differentiation, CFU assay, immunocytochemistry, flow cytometry, RT-PCR. Results. The obtained NC-MSCs expressed the typical neural crest markers (nestin, Sox10 and Sox2) and were differentiated into adipocytes, osteoblasts and Schwann cells. Under our original growing conditions, the culture of NC-MSCs at the third passage had the following parameters: $66.8 \%$ nestin, $3.1 \%$ $A L D H^{\text {brigth }}$ and $33.3 \%$ clonogenic cells. The NC-MSCs growth rate depended on plating density. EGF and bFGF demonstrated a dose-dependent mitogenic action on NC-MSCs. Conclusions. The proposed approach permits the NC-MSC expansion with the maintenance of their main functional properties. Further optimization of the culture conditions will be based on the use of growth factors and low plating density.
\end{abstract}

Keywords: neural crest, multipotent stem cells, colony-forming units, plating density, growth factors.

Introduction. In the recent 15 years the neural crestderived multipotent stem cells (NC-MSCs) have been isolated from various tissues and organs of adult mammals (for review see [1]). The given cell type is of great interest for the basic research in cell biology as well as for the practical application in the regenerative medicine. This is explained by the NC-MSCs capacity for self-renewal and differentiation into multiple cell types such as neurons, Schwann cells, corneal stromal (keratocytes) and endothelial cells, melanocytes, osteoblasts, etc.

NC-MSCs exist in various adult mammalian tissues as a minor cell population. For their practical use

(C) Institute of Molecular Biology and Genetics, NAS of Ukraine, 2014 in regenerative medicine, reliable and reproducible methods are needed for their expansion. The majority of NC-MSCs culturing protocols use a combination of the chick embryo extract (CEE) and fetal bovine serum (FBS) as growth supplements [2]. The CEE and FBS have an undefined, complicated and variable composition. As a commercial product the CEE is now very rarely produced by few companies and predominantly as a protein-free ultrafiltrate unable to maintain NCMSCs expansion. The CEE production in laboratory is a complicated and labor-consuming process. Thus a creation of the GMP-compliant xeno-free media for the NC-MSCs culturing for clinical application is very actual. For the human cell culture a successful replacement of FBS by human blood derivatives (e. g. platelet 
lysate) was shown [3]. Hence the development of CEEfree growth media for NC-MSCs is a great challenge.

The second aspect of the NC-MSCs culture is a search for the markers of stemness. The clonal analysis performed by us and others has shown that at early culture stages the cells are heterogenic by their clonogenic potential $[2,4]$. In other words, not all of the cells in culture are stem cells. A clonal analysis is the gold standard for determination of the amount of stem/progenitor cells in culture or tissue samples. However, this is a time-consuming process allowing only a retrospective assessment.

Nestin is thought to be one of the most popular markers of neural stem/progenitor cells and NC-MSCs [2, 5]. It is the class VI intermediate filament protein with a cytoplasmic localization and thus it is technically unsuitable for the isolation of live positive cells. Currently the role of nestin as a marker of stem cells and the idea of its exclusive expression in the neural and neural crest cells are re-estimated [6]. Nowadays there are no phenotypic markers that allow identifying and isolating NC-MSCs from the committed cells with a limited proliferative potential (progenitor cells). Search for the markers suitable for the prospective evaluation and selection of NC-MSCs is very actual. A perspective nonimmunological method is the identification of the stem/ progenitor cells based on a high activity of aldehyde dehydrogenase (ALDH). High ALDH expression has been reported for normal and cancer stem/precursor cells of various lineages including hematopoietic, mammary, endothelial, mesenchymal, and neural (for review see [7]). The ALDH activity for NC-MSCs has not been estimated so far.

Our aims were to obtain the NC-MSCs culture from the bulge region of the whisker follicle of adult mice in the new CEE-free culture conditions, (b) to confirm the NC-MSCs identity, (c) to investigate functional signs and markers of stemness in culture (clonogenicity, number of nestin ${ }^{+}$and $\mathrm{ALDH}^{\text {brigth }}$ cells), (d) to assess effects of plating density and growth factors on the NC-MSCs proliferation.

Materials and methods. Our experiments were done in accordance with the bioethics and biological safety norms and confirmed by the conclusion of the Bioethical Committee of the State Institute of Genetic and Regenerative Medicine NAMS of Ukraine. Five cell cultures obtained from males of FVB strain 4-6month old mice were used.

Isolation and culturing of NC-MSCs from the bulge region (BR) of the whisker follicle (WF). NC-MSCs were isolated using an explants technique from the BR of the WF according to Sieber-Blum et al. [2]. Briefly, the specimens of BR were obtained via microdissection of WF under stereomicroscope. Afterwards each three explants were placed in the collagen-coated $35 \mathrm{~mm}$ Petri dish and cultured in the multigas incubator CB210 («BINDER», Germany) at $37^{\circ} \mathrm{C}$, saturated humidity in the artificial atmosphere containing $90 \%$ of $\mathrm{N}_{2}, 5 \%$ of $\mathrm{O}_{2}$ and $5 \%$ of $\mathrm{CO}_{2}$ in the following growth medium: DMEM:F12 («Sigma») supplemented with $10 \%$ fetal bovine serum (FBS) («Sigma»), 1\% vitamins MEM («Sigma»), 2 mM glutamine («Sigma»), $2 \%$ B27 («Gibco», USA) and $2 \%$ insulin, transferrin, selenium (ITS) supplements («BD», USA). On day 11 the explants were discarded and the cells were subcultured into T25 flask. All culture dishes were coated with type I collagen. When subcultured, the cells were dissociated with $0.05 \%$ trypsin in $0.53 \mathrm{mM} \mathrm{Na}_{2}$-EDTA («Sigma»).

In order to check the NC-MSC phenotype and contamination by other cell types, a part of the explants was plated on a cover glass. The cells of primary culture were stained on day 11 as described below (Immunofluorescent staining section). For the rest of experiments we used the $3^{\text {rd }}$ passage cells.

Sphere-forming assay. The cells were dissociated and washed twice by phosphate buffered saline (PBS, $\mathrm{pH}$ 7.4) with centrifugation ( $200 \mathrm{~g}, 5 \mathrm{~min}$ ) to get rid of the serum residues and then plated in the concentration $10^{4}$ cells $/ \mathrm{ml}$ in the $35 \mathrm{~mm}$ Petri dish for suspension cell culture in the serum-free medium containing: DMEM: F12, 2 \% B27 supplement, $2 \mathrm{mM}$ glutamine, $20 \mathrm{ng} / \mathrm{ml}$ basic fibroblast growth factor (bFGF, FGF-2) («Sigma», USA ), $40 \mathrm{ng} / \mathrm{ml}$ epidermal growth factor (EGF) («Sigma»). The growth factors were added each $48 \mathrm{~h}$. Half of the medium was changed once a week. The cells were cultured for 14-21 days.

Directed multilineage differentiation. Adipogenic differentiation was performed in the following medium: DMEM with high glucose content (4.5 g/l) («Sigma») with $5 \%$ horse serum («PAA», Austria), $10 \%$ FBS, 1 $\mu \mathrm{M}$ dexamethasone, $200 \mu \mathrm{M}$ indomethacine, $500 \mu \mathrm{M}$ isobutylmethylxanthine and $5 \mu \mathrm{g} / \mathrm{ml}$ insulin («Sigma»). 
After 14 days the cells were fixed and stained. To detect adipogenic differentiation, the cells were stained with Oil Red O («Sigma»).

Osteogenic differentiation was performed in the following medium: DMEM with low glucose content $(1 \mathrm{~g} / 1)$ with $10 \%$ FBS, $100 \mathrm{nM}$ dexamethasone, $10 \mathrm{mM}$ $\beta$-glycerophosphate and $50 \mu \mathrm{g} / \mathrm{ml}$ ascorbate-2-phosphate («Sigma»). After 21 days the cells were fixed and stained. To detect osteogenic differentiation, the cells were stained with Alizarin Red S («Sigma»).

Differentiation into glial cells (Schwann cells) was done in Neuronal Medium («PAA») with $10 \%$ mouse brain extract, $1 \%$ B27 («Gibco»), $2 \mu \mathrm{M}$ retinoid acid and $2 \mu \mathrm{M}$ forskolin («Sigma»). After 14 days the cells were fixed and stained.

Colony-forming units (CFU) assay. Two hundred cells of each cell culture were seeded in triplicate on the $100 \mathrm{~mm}$ Petri dishes in the growth medium (FBS concentration was increased to $20 \%$ ). The cells were grown during 14 days. The colony-forming efficiency (CFE) was estimated according to the standard formula: $\mathrm{CFE}=$ (number of colonies formed/number of cells plated) $\cdot 100 \%$ [8]. To assess the types of CFU, the cultures were stained with Romanovsky-Gimsa («Macrochim», Ukraine).

Flow cytometry. The number of nestin ${ }^{+}$and $\mathrm{ALDH}^{\text {brigth }}$ cells was measured on the flow cytofluorimeter-sorter BD FACSAria («BD»). Staining by monoclonal antinestin (PE) antibodies was performed according to the manufacturer's instructions («BD»). ALDH ${ }^{\text {brigth }}$ cells were identified using the ALDEFLUOR ${ }^{\mathrm{TM}}$ kit ( $« \mathrm{STEM}$ CELL Technologies», Canada) according to the manufacturer's instructions.

RT-PCR analysis. Cells were harvested by trypsinization and washed by PBS. Total cellular mRNA was isolated by the column-based kit «NucleoSpin RNA» («Macherey-Nagel», Germany) according to the manufacturer's instructions. cDNA were synthesized with the RevertAid First Strand cDNA Synthesis Kit using oligo(dT) primer («Thermo Scientific», USA) according to the manufacturer's instructions.

For the detection of Sox 10 and Sox 2 mRNA expression we used the following primers:

Sox $10-$

F: 5'-GACTGGACGCTGGTGCCCATGCCC-3', R: 5'- CCGTTCTTCCGCCGCCGAGGTTG-3';
Sox $2-$

F: 5'-TCACAACAATCGCGGCGG-3', R: 5'-GTTCATGTGCGCGTAGCTGT-3'.

To evaluate the quality of purified RNA, a control RT-PCR was performed using the GAPDH primers from the kit («Thermo Scientific»). For the DNA contamination control we used the samples without reverse transcriptase.

Immunofluorescent staining of cells. NC-MSCs were fixed with Cytofix reagent («Sigma») for $30 \mathrm{~min}$ at room temperature, washed twice with PBS («Sigma»), then permeabilized with $0.1 \%$ Triton X-100 («Sigma») for $10 \mathrm{~min}$, washed twice with PBS, saturated with $4 \%$ bovine serum albumin (BSA) («Sigma») for $30 \mathrm{~min}$ and stained with FITC-conjugated anti-pancytokeratin mouse antibodies (1:50, «Sigma») and primary rabbit antinestin antibodies (1:100, «Sigma») for $1 \mathrm{~h}$ at room temperature. The cells were washed three times with PBS and incubated with secondary goat anti-rabbit Alexa 594-conjugated antibodies (1:2000, «Abcam», UK) for $1 \mathrm{~h}$ and washed two more times with PBS. Glial differentiation was detected with primary mouse anti-S-100 $(1: 500$, «Abcam») and secondary goat anti-mouse fluorescein isothiocyanate (FITC)-conjugated antibodies $(1: 2000$, «Abcam»).

Cell nuclei were contrasted with Hoechst 33342 (2 $\mu \mathrm{g} / \mathrm{ml}$ ) or propidium iodide (PI, $2 \mu \mathrm{g} / \mathrm{ml}$ ) for $10 \mathrm{~min}$ after the incubation with the secondary antibodies. Then the cells were washed two times with PBS and mounted in Mowiol («Sigma»).

Estimation of plating density effect on growth rate. Cells were plated into T25 flasks (in triplicate) with plating density 10,50,100, 1000 and 5000 cells $/ \mathrm{cm}^{2}$ and cultured for 7 days (change of the medium was done every $48 \mathrm{~h}$ ). Thereafter the cells were calculated. The cell population doubling number (PDN) and the population doubling time (PDT) were estimated according to the standard formula: $\mathrm{PDN}=3.32 \cdot \lg \left(X_{\mathrm{k}} / X_{0}\right)$ and PDT $=$ $=\mathrm{T} / 3.32 \cdot \lg \left(X_{\mathrm{k}} / X_{0}\right)$, where $X_{\mathrm{k}}$ - number of expanded cells; $X_{0}$ - number of plated cells; $\mathrm{T}$ - cell culture time [8].

Assessment of growth factors effect on proliferation. The cells were seeded on 6-well plates (in triplicate) with plating density $1000 \mathrm{cells} / \mathrm{cm}^{2}$ and cultured for 7 days in the standard growth medium (control) or in the growth medium supplemented with EGF (5, 10, 20 and $50 \mathrm{ng} / \mathrm{ml})$ or bFGF $(1,2,5$ and $10 \mathrm{ng} / \mathrm{ml})$. The medium 


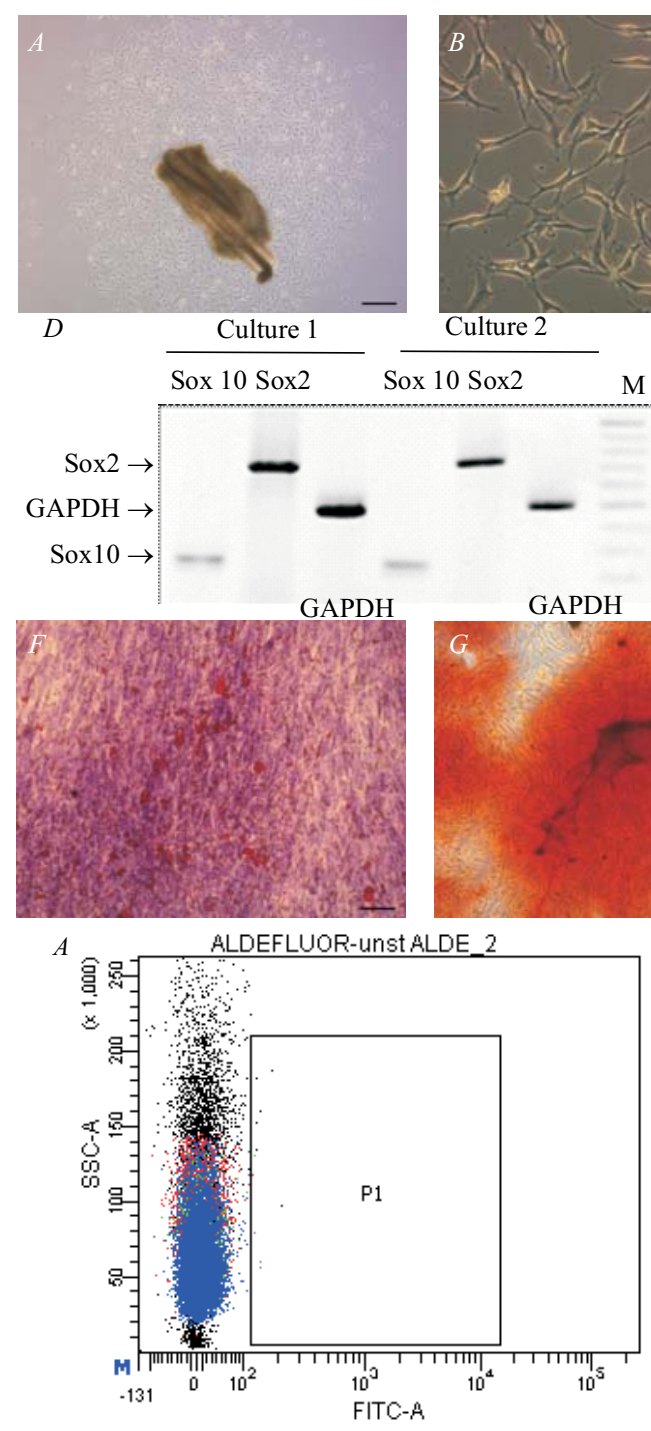

A

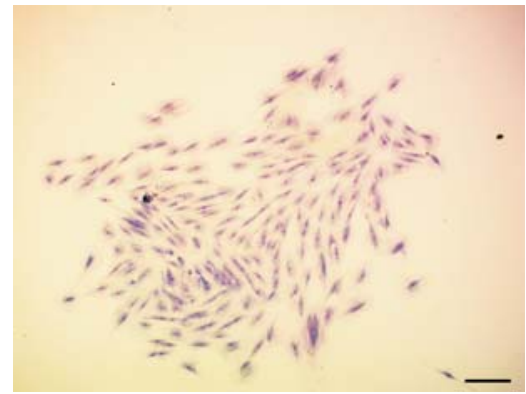

C

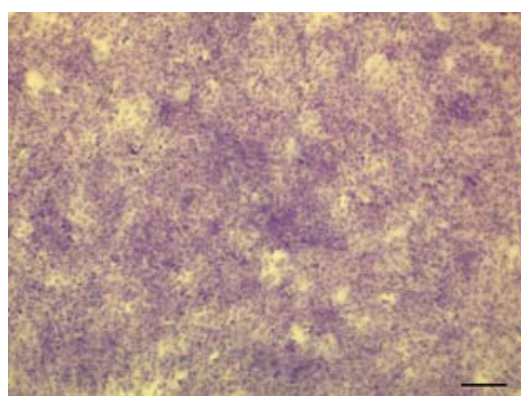

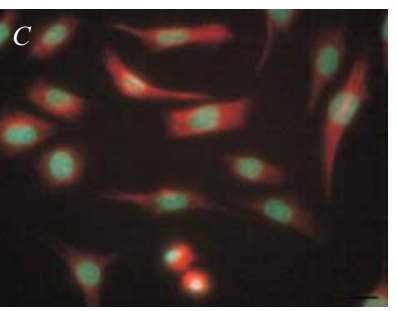

E bp

$\leftarrow 1000$

$\leftarrow 500$

$\leftarrow 200$

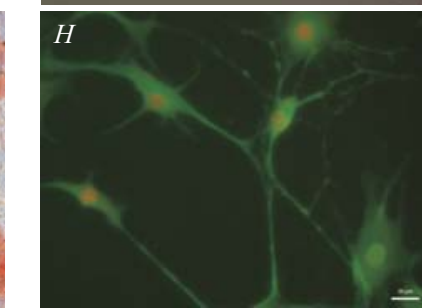

B

ALDEFLUOR-ALDEFLUOR 2

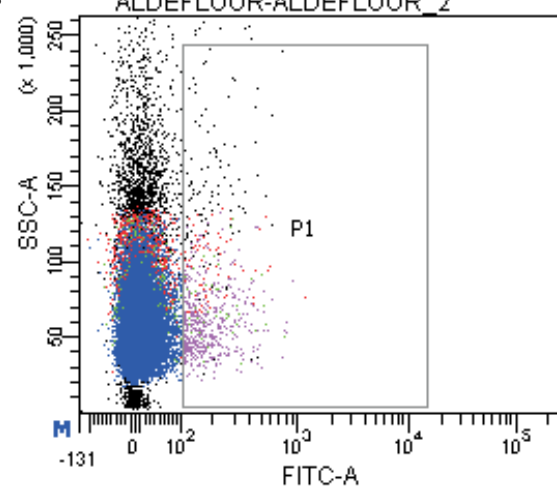

FITC-A

$B$

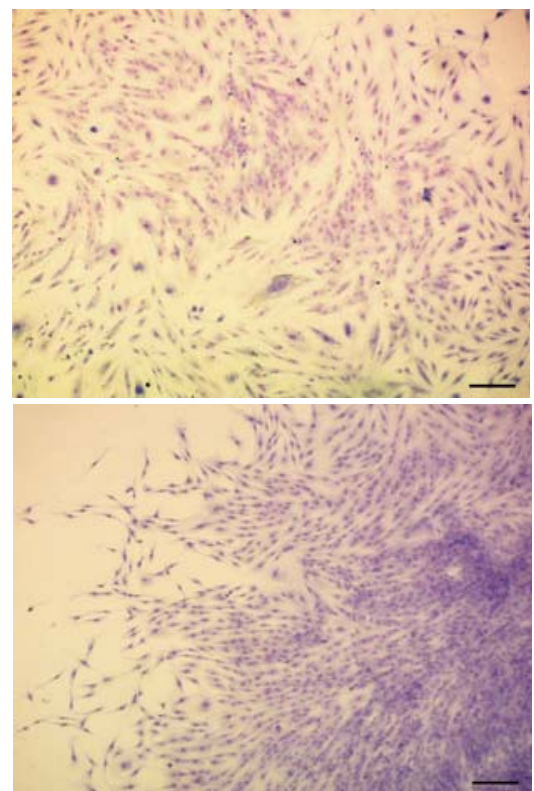

Fig. 1. Morphology, phenotype and functional properties of NC-MSCs: $A-$ an explant of BR WF with migrating NC-MSCs, 11 days of primary culture, phase contrast, scale $200 \mu \mathrm{m} ; B-$ the morphology of NC-MSCs, phase contrast, scale $50 \mu \mathrm{m} ; C$ - NC-MSCs are nestin ${ }^{+}$(red) cytokeratin (green), scale $20 \mu \mathrm{m} ; D$ - RT-PCR analysis of the expression of $\mathrm{NC}$ markers in two NC-MSC cultures (M - 100 bp DNA ladder; RT- - control without reverse transcriptase); $E$ - NC-MSCs form spheres in serum-free conditions, phase contrast, scale $20 \mu \mathrm{m} ; F$ - adipogenic differentiation of NC-MSCs, Oil Red stain, scale $200 \mu \mathrm{m}$; $G$ - osteogenic differentiation of NC-MSC, Alizarin Red stain, scale $200 \mu \mathrm{m} ; H$ - differentiation of NC-MSC into Schwann cells, anti-S-100 stain (green), fluorescent microscopy, scale $20 \mu \mathrm{m}$

Fig. 2. ALDH ${ }^{\text {bright }}$ cell detection in the $3^{\text {rd }}$ passage culture of NC-MSCs: $A-$ control (cells treated with the inhibitor of ALDH; $B$ - tested cells. P1 population of $\mathrm{ALDH}^{\text {bright }}$ cells

Fig. 3. Clonal heterogeneity of NCMSCs: $A$ - type I CFU; $B$ - type II CFU; $C$ - type III CFU (colony center with high cell density and 3D structures formation (spheroids)); $D$ - type III CFU (colony periphery with actively migrating fibroblast-like cells). Romanowsky-Giemsa stain, scale $200 \mu \mathrm{m}$ 
Parameters of NC-MSC cultures at the $3^{\text {rd }}$ passage

\begin{tabular}{c|c|c|c|c|c|c|}
\hline $\begin{array}{c}\text { Cell culture, } \\
\mathrm{N}\end{array}$ & Nestin ${ }^{+}$cells, \% & ALDH $^{\text {bright }}$ cells, \% & $\begin{array}{c}\text { Colony-forming } \\
\text { efficiency, \% }\end{array}$ & $\begin{array}{c}\text { Type I colony- forming units } \\
\text { (CFU), \% of plated cells }\end{array}$ & $\begin{array}{c}\text { Type II CFU, \% of plated } \\
\text { cells }\end{array}$ & $\begin{array}{c}\text { Type III CFU, \% of plated } \\
\text { cells }\end{array}$ \\
\hline 1 & 69.8 & 3.5 & 35.8 & 12.0 & 20.2 & 3.6 \\
2 & 67.6 & 3.1 & 31.7 & 10.2 & 18.5 & 3.0 \\
3 & 74.6 & 4.7 & 38.0 & 12.0 & 20.8 & 5.2 \\
4 & 59.8 & 1.9 & 29.0 & 9.4 & 17.8 & 1.8 \\
5 & 62.3 & 2.1 & 32.2 & 8.7 & 21.3 & 2.2 \\
$M \pm s$ & $66.82 \pm 5.91$ & $3.06 \pm 1.13$ & $33.33 \pm 3.57$ & $10.43 \pm 1.53$ & $19.73 \pm 1.51$ & $3.12 \pm 1.33$ \\
\hline
\end{tabular}

was changed every $48 \mathrm{~h}$. The cell number was calculated on days 3,5 and 7 .

Cell counting and viability assay. The cell number and viability were estimated after staining with $0.4 \%$ trypan blue. The living and dead cells were counted using the Goryaev chamber. The cell viability (CV) was estimated according to the standard formula: $\mathrm{CV}=$ (number of viable cells/ total cell number) $\cdot 100 \%$ [8].

Microscopy. Inverted fluorescent microscope Axio Observer A1 equipped with digital camera AxioCam ERc 5s and ZEN 2012 («Carl Zeiss», Germany) software was used.

Statistics. The data are presented as means and standard deviation $(M \pm s)$. Statistical significance was estimated using the Student's $t$-criterion.

Results and discussion. Under proposed culture conditions cell migration from the BR explants and their active proliferation began on day 4. It was previously shown that the culture from BR of WF besides NCSC may also contain other cell types such as epidermal stem cells and keratinocytes $[2,9]$. To check the purity and homogeneity of the obtained cultures we analyzed cell morphology (fibroblast-like for NCSC vs epithelial-like for keratinocytes) and expression of the specific markers (nestin for NCSC and cytokeratin for keratinocytes). All cells in primary culture had a characteristic fibroblast-like morphology and were nestin ${ }^{+}$cytokeratin ${ }^{-}$(Fig. 1, $A, B$, $C$ ). They also expressed transcription factors Sox 10 (one of the central regulators of neural crest development, which maintains neural crest cell identity) [10] and Sox 2 (a marker of early neuroepithelial cells, factor of pluripotency and stemness, reexpressed in adult NC-MSCs) [11] (Fig. 1, D). Thus the cells expressed main phenotypic markers of the neural crest-derived cells.
Next, we expanded the cells up to $3^{\text {rd }}$ passage and studied their functional properties. Importantly, the $3^{\text {rd }}$ passage allowed obtaining a sufficient number of cells for most experimental and potential clinical applications. When cultured in serum-free conditions the $3^{\text {rd }}$ passage NC-MSCs formed floating spheres like neurospheres formed by neural stem cells (Fig. 1,E). The cells also possessed the capacity for a directed differentiation into adipocytes, osteoblasts and glial cells (Fig. 1, $F, G, H)$. Thus the cells expanded in our culture conditions corresponded to the NC-MSCs criteria [1].

The study on functional and phenotypic markers of stemness in $3^{\text {rd }}$ passage cultures revealed that at a given time point the number of nestin ${ }^{+}$cells was $66.82 \pm 5.91 \%$ and the CFE was $33.33 \pm 3.57 \%$ (Table). Besides, a minor subpopulation of $\mathrm{ALDH}^{\text {bright }}$ cells $(3.06 \pm 1.13 \%)$ was present in the NC-MSCs culture (Fig. 2, Table). An analysis of the colonies formed in the CFU assay showed that the $3^{\text {rd }}$ passage NC-MSCs were heterogenic in their proliferative potential. Depending on the cell number, all CFUs could be divided into three types: type I CFU consisted of 50-100 cells; type II CFU consisted of 100-300 cells; and type III CFU (about 1000 cells) (Fig. 3, Table). Earlier we showed that only type III CFUs were able to form secondary clonal colonies $[4,12]$. Noteworthy, the subcloning of type III CFU resulted in the appearance of all the three types of colonies again $[4,12]$. Thus, type III CFUs possess the ability for self-renewal. Previously we had also shown that the clonal cultures from type III CFUs maintain the ability for directed multilineage differentiation into adipocytes, osteoblasts, neurons and Schwann cells [13]. Therefore, the type III CFUs in vitro manifest the main functional signs of stem cells, i. e. self-renewal and mul- 

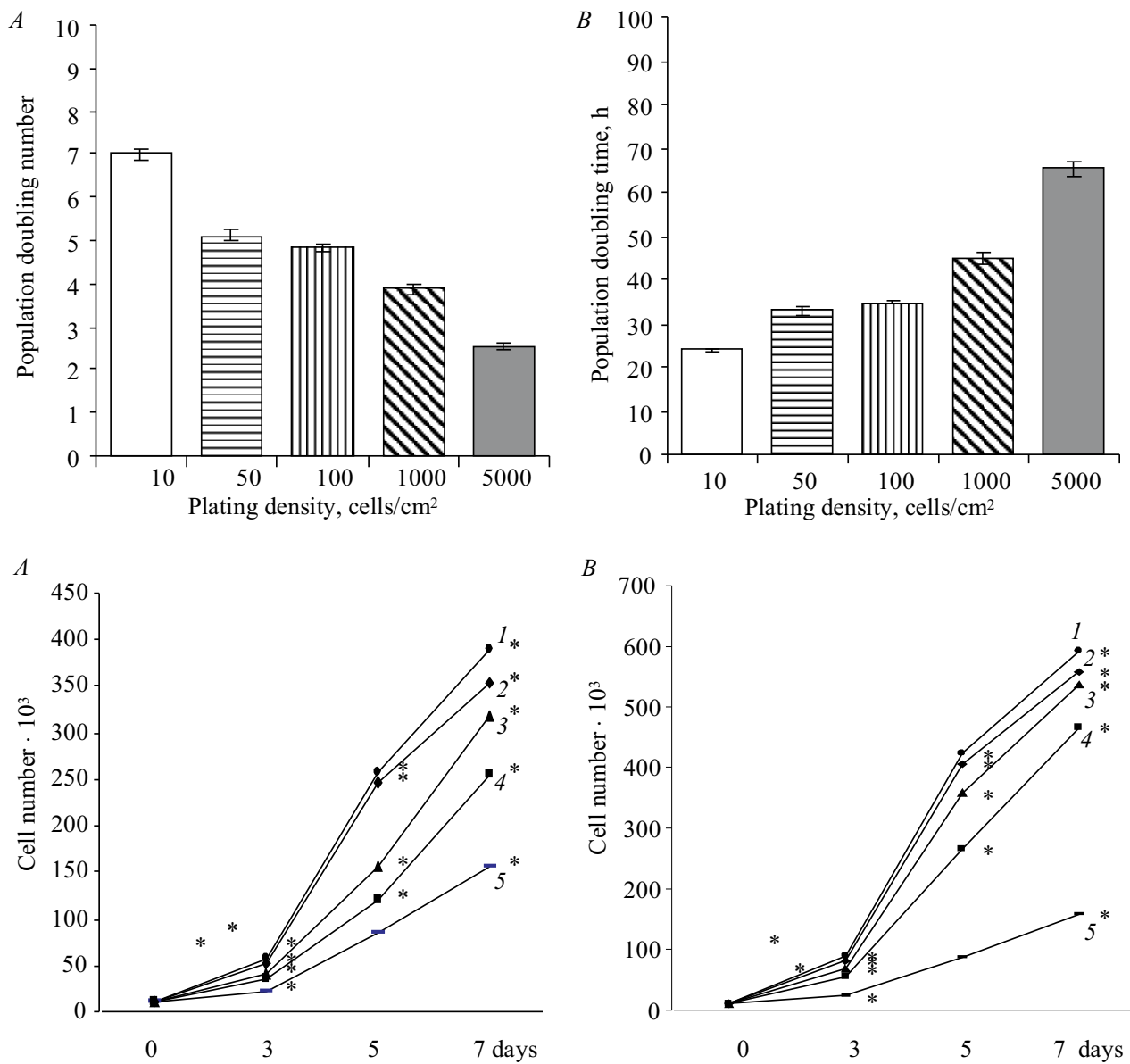

$B$

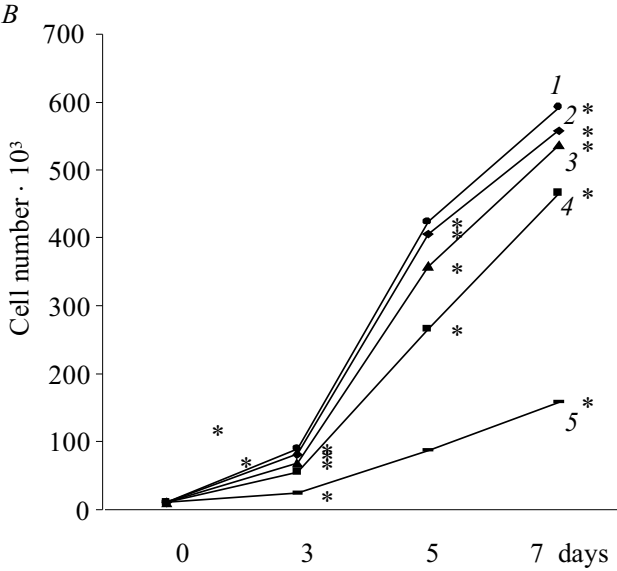

Fig. 4. Effects of plating density on NC-MSC growth rate: $A$ - population doubling number; $B$ - population doubling time. ${ }^{*} \mathrm{p}<0.05$
Fig. 5. Effect of the growth factors on NC-MSC proliferation. Growth curve of NC-MSCs cultured with different concentration of EGF $(A$ : $1-50 \mathrm{ng} / \mathrm{ml} ; 2-20 \mathrm{ng} / \mathrm{ml} ; 3-10$ $\mathrm{ng} / \mathrm{ml} ; 4-5 \mathrm{ng} / \mathrm{ml} ; 5$ - control) and bFGF $(B: 1-10 \mathrm{ng} / \mathrm{ml} ; 2-5 \mathrm{ng} / \mathrm{ml}$; $3-2 \mathrm{ng} / \mathrm{ml} ; 4-1 \mathrm{ng} / \mathrm{ml} ; 5-$ control). ${ }^{*} \mathrm{p}<0.05$ tilineage differentiation and hence their founder cells are the NC-MSCs per se.

For further optimization of the NC-MSC culture conditions we studied the effects of plating density and growth factors (bFGF and EGF) on the cell growth rate. NC-MSCs show strong dependence of growth rate on plating density (Fig. 4). The highest growth rate was observed at the lowest plating density $\left(10\right.$ cells per $\left.\mathrm{cm}^{2}\right)$ : the population doubling number was almost three times bigger whereas the population doubling time was three times less than that of the cells with high plating density $\left(5000\right.$ cells per $\left.\mathrm{cm}^{2}\right)$. We found that in given conditions the optimal cell plating density for NC-MSCs is $50-100$ cells per $\mathrm{cm}^{2}$ that allows fast and steady expansion.

As for the growth factors effect, both bFGF and EGF produced a dose-dependent mitogenic effect (Fig. 5). Notably, the bFGF effect was more pronounced and appeared at lower concentrations: $1 \mathrm{ng} / \mathrm{ml}$ of bFGF was enough to increase the cell number three times comparing to the control. A higher bFGF concentration (from
2 to $10 \mathrm{ng} / \mathrm{ml}$ ) gave similar curves and about 4 -fold increase in the cell number. EGF had less striking effect and at the concentration of $10 \mathrm{ng} / \mathrm{ml}$ only doubled the NC-MSCs number comparing to the control.

Studies on NC-MSCs and development of culture methods for their expansion are an actual and complex task. It was believed for a long time that NC-MSCs have the transitory nature similar to neural crest and exist only in the narrow time span during embryonic development. In recent 15 years this concept has changed in view of the isolation of cells possessing NC-MSC properties from many tissues of adult mammals. However, their study is very challenging.

Firstly, NC-MSCs exist in adult organism tissues in the form of minor population and currently there are no phenotypic markers for their discrimination from the cells of mesenchymal origin. Secondly, several of the neural crest-derived differentiated cell types, such as melanocytes and Schwann cells, possess the capacity for dedifferentiation and subsequent multilineage differen- 
tiation into other cell types $[14,15]$. As has been already mentioned, the phenotypic markers of NC-MSCs allowing their distinction from the neural crest-derived differentiated cells are lacking.

The engineering of special transgenic mice strains allowed solving the problem of isolation of neural crestderived cells from an adult organism for the investigation of their biological properties [16]. It was shown that BR of WF is the convenient source for the isolation of NC-MSCs and a significant part of cells in the primary culture appears to be stem cells [2]. According to our results, the culture of neural crest-derived cells has the hierarchic organization and is composed of three cell subpopulations:

a) stem cells with a large proliferative potential that are capable of self-renewal (type III CFU);

b) progenitor cells with a moderate proliferative potential that are incapable of self-renewal (type II CFU);

c) differentiated cells with limited proliferation capacity (type I CFU).

Such hierarchic organization of the cells in culture was reported by other authors for the NC-MSCs obtained from different tissues and organs [2, 17].

As we demonstrated the number of nestin ${ }^{+}$cells greatly exceeds the number of type III CFU. Thus nestin is rather the marker of a proliferative state than the stem-like state of neural crest-derived cells.

We were first to demonstrate the existence of ALDH $^{\text {bright }}$ cells in the culture of neural crest-derived cells. Interestingly, the number of ALDH ${ }^{\text {bright }}$ cells in the culture is comparable with the number of type III CFU. Further investigations are needed to separate the $\mathrm{ALDH}^{\text {bright }}$ and $\mathrm{ALDH}^{\mathrm{dim}}$ subpopulations and compare their proliferative and clonogenic potential. Similar to other cell types [7] the activity of ALDH may appear to be the marker of stem cells in the population of neural crest-derived cells.

According to our data, the growth rate of NCMSCs depends on plating density. Such dependence was first demonstrated for the bone marrow mesenchymal stem cells (BMMSCs) from different species [18]. Apparently, this phenomenon is the consequence of a hierarchic organization of the BMMSCs in culture [18]. Later these data were used to work out the effective protocols for the BMMSCs expansion for clinical applications, when the time necessary for receiving the therapeutic cell doses is crucial [19].

The use of a serum-based medium with hormonal supplements and hypoxia allows an effective expansion of NC-MSCs from BR of WF. Further search for the growth factors promoting NC-MSCs self-renewal is necessary to increase the number of type III CFU in culture. The effect of growth factors on the fetal neural crest stem cells has been thoroughly studied [20]. However, the adult NC-MSCs are prone to change their responsiveness to the certain of them [21]. For this reason, in the case of adult NC-MSCs the impact of growth factors on proliferation and differentiation should be determined anew [21]. EGF and bFGF were empirically used in the serum-free growth medium composition for the assessing of NC-MSC sphere-forming capacity [16]. We demonstrated that EGF and bFGF possess potent mitogenic action when used in the serum-based growth medium. In our future investigations we plan to explore the effects of the given growth factors on the NC-MSC clonogenic capacity and the frequency of the appearance of different $\mathrm{CFU}$ types.

Conclusions. Our findings open new aspects for the NC-MSC biology and can promote translation of the experimental therapeutic methods based on NC-MSCs into the clinical practice of regenerative medicine.

Біологічні властивості мультипотентних стовбурових клітин похідних нервового гребеня з бульбарного району волосяного фолікула вібриса при їхньому нарощуванні за нових умов культивування

Р. Г. Васильєв, А. С. Родніченко, Д. О. Зубов, С. Ю. Римар, О. С. Губар, І. Ф. Лабунець, С. М. Новікова

Резюме

Мета. Отримати культуру мультипотентних стовбурових клітин - похідних нервового гребеня (МСК-ПНГ) за нових умов культивування та дослідити їхні біологічні властивості. Методи. МСК-ПНГ отримували з експлантів бульбарного району волосяного фолікула вібриса дорослих мишей. Культури клітин вивчали з використанням наступних методів: дослідження на здатність до сфероутворення, направлене мультилінійне диференціювання, тест на колонієутворювальну здатність, імуноцитохімія, проточна цитометрія, 3Т-ПЛР. Результати. Отримані МСК-ПНГ експресували характерні для нервового гребеня маркери (нестин, Sох10 и Sох2) та диференціювалися в адипоцити, остеобласти та Шванівські клітини. У запропонованих нами умовах культура МСК-ПНГ на третьому пасажі містила: 66,8 \% нестину ${ }^{+}, 3,1$ $\%$ ALDH ${ }^{\text {brigth }}$ и 33,3\% колонієутворювальних клітин. Встановлено, щзо швидкість росту МСК-ПНГ залежсть від щиільності посіву. Виявлено дозозалежну мітогенну дію EGF і bFGF на MCK-ПНГ. 
Висновки. Розроблено новий підхід, щзо дозволяє нарощувати МСК-ПНГ із збереженням їхніх основних функиіональних властивостей. Подальша оптимізація умов культивування буде заснована на використанні факторів росту і низької щзільності посіву.

Ключові слова: нервовий гребінь, мультипотентні стовбурові клітини, колонієутворювальні одиниці, щиільність посіву, фактоpu pocmy.

Биологические свойства мультипотентных стволовых клеток производных нервного гребня из бульбарного района волосяного фолликула вибрисса, размноженных в новых условиях культивирования

Р. Г. Васильев, А. Е. Родниченко, Д. А. Зубов, С. Е. Рымарь, О. С. Губарь, И. Ф. Лабунец, С. Н. Новикова

\section{Резюме}

Цель. Получить культуру мультипотентных стволовых клеток - производных нервного гребня (МСК-ПНГ) в новых культуральных условиях и исследовать их биологические свойства. Методы. МСК-ПНГ получали из эксплантов бульбарного района волосяного фолликула вибрисса взрослых мылей. Культуры клеток изучали следуюшими методами: исследование на способность к сферогенезу, направленная мультилинейная дифференциация, тест на колониеобразуюшую способность, иммуночитохимия, проточная иитометрия, ОТ-ПЦР. Результаты. Полученные МСК-ПНГ экспрессировали характерные маркеры нервного гребня (нестин, Sох10 и Sох2) и дифферениировались в адипоцить, остеобласть и Шванновские клетки. В предложенных нами условиях культура МСК-ПНГ на третьем пассаже содержала: 66,8\% нестина , 3,1 $\%$ ALDH ${ }^{\text {brigth }}$ и 33,3\% колониеобразующих клеток. Определено, что скорость роста МСК-ПНГ зависит от плотности посева. Показано дозозависимое митогенное действие EGF и bFGF на МСК-ПНГ. Выводы. Предложен подход, позволяюший наращчивать МСК-ПНГ с сохранением их основных функииональных свойств. Дальнейшая оптимизация условий культивирования будет основана на использовании факторов роста и низкой плотности посева.

Ключевые слова: нервный гребень, мультипотентные стволовые клетки, колониеобразуючие единицы, плотность посева, факторы роста.

\section{REFERNCES}

1. Achilleos A, Trainor PA. Neural crest stem cells: discovery, properties and potential for therapy. Cell Res. 2012;22(2):288-304.

2. Sieber-Blum M, Grim M, Hu YF, Szeder V. Pluripotent neural crest stem cells in the adult hair follicle. Dev Dyn. 2004;231(2):258-69.

3. Bieback K, Hecker A, Kocaomer A, et al. Human alternatives to fetal bovine serum for the expansion of mesenchymal stromal cells from bone marrow. Stem Cells. 2009;27(9):2331-41.

4. Vasyliev RG, Rodnichenko AE, Zubov DO, et al. Investigation in vitro of biological properties of neural crest-derived multipotent stem cells from bulge region of hair follicle of adult mammals. Stem cells and regenerative medicine. Ed. VA. Tkachuk. Moscow, MSU Press, 2014; 39-57.
5. Park D, Xiang AP, Mao FF, et al. Nestin is required for the proper self-renewal of neural stem cells. Stem Cells. 2010;28(12): 2162-71.

6. Suzuki S, Namiki J, Shibata S, Mastuzaki Y, Okano H. The neural stem/progenitor cell marker nestin is expressed in proliferative endothelial cells, but not in mature vasculature. J Histochem Cytochem. 2010;58(8):721-30.

7. Ma I, Allan AL. The role of human aldehyde dehydrogenase in normal and cancer stem cells. Stem Cell Rev. 2011;7(2):292-306.

8. Freshney RI. Culture of animal cells: a manual of basic technique and specialized applications. $6^{\text {th }}$ Ed. Wiley-Blackwell, 2010; 796 p.

9. Cotsarelis $G$. Epithelial stem cells: a folliculocentric view. J Invest Dermatol. 2006;126(7):1459-68.

10. Kelsh RN. Sorting out Sox 10 functions in neural crest development. Bioessays. 2006;28(8):788-98.

11. Johnston AP, Naska S, Jones K, Jinno H, Kaplan DR, Miller FD. Sox2-mediated regulation of adult neural crest precursors and skin repair. Stem Cell Reports. 2013;1(1):38-45.

12. Vasyliev RG, Rodnichenko AE, Zubov DA, Labunets IF, Novikova $S N$, Butenko GM. In vitro properties of neural crest-derived multipotent stem cells from a bulge region of whisker follicle. Biotechnologia Acta. 2014; 7(4):71-9.

13. Vasyliev $R G$. Clonal multipotency of neural crest-derived stem/ progenitors cells from bulge region of adult mammal hair follicle. Problems of Cryobiology and Cryomedicine. 2013; 23(3): 279-82.

14. Motohashi T, Yamanaka K, Chiba K, Aoki H, Kunisada T. Unexpected multipotency of melanoblasts isolated from murine skin. Stem Cells. 2009;27(4):888-97.

15. Adameyko I, Lallemend F, Aquino JB, et al. Schwann cell precursors from nerve innervation are a cellular origin of melanocytes in skin. Cell. 2009;139(2):366-79.

16. Wong CE, Paratore C, Dours-Zimmermann MT, et al. Neural crest-derived cells with stem cell features can be traced back to multiple lineages in the adult skin. J Cell Biol. 2006;175(6): 1005-15.

17. Trentin A, Glavieux-Pardanaud C, Le Douarin NM, Dupin E. Self-renewal capacity is a widespread property of various types of neural crest precursor cells. Proc Natl Acad Sci U S A. 2004; 101(13):4495-500.

18. Javazon EH, Colter DC, Schwarz EJ, Prockop DJ. Rat marrow stromal cells are more sensitive to plating density and expand more rapidly from single-cell-derived colonies than human marrow stromal cells. Stem Cells. 2001;19(3):219-25.

19. Mareschi K, Rustichelli D, Calabrese R, et al. Multipotent mesenchymal stromal stem cell expansion by plating whole bone marrow at a low cellular density: a more advantageous method for clinical use. Stem Cells Int. 2012;2012:920581.

20. Sieber-Blum M, Zhang JM. Growth factor action in neural crest cell diversification. J Anat. 1997;191 (Pt 4):493-9.

21. Kruger GM, Mosher JT, Bixby S, Joseph N, Iwashita T, Morrison SJ. Neural crest stem cells persist in the adult gut but undergo changes in self-renewal, neuronal subtype potential, and factor responsiveness. Neuron. 2002;35(4):657-69.

Received 30.09.14 